\title{
Influence of season of birth, sex and paternal line on growth performance and carcass traits in pigs
}

\author{
J.H. Lee ${ }^{1 *}$, M.H. Song ${ }^{2 *}$, W. Yun ${ }^{1}$, S.D. Liu ${ }^{1}$, C.H. Lee ${ }^{1}$, H.J. Oh ${ }^{1}$, J.S. An ${ }^{1}$, D.J. Yu ${ }^{3}$, H.B. Kim ${ }^{4 \#} \&$ \\ J.H. Cho ${ }^{1 \#}$ \\ ${ }^{1}$ Division of Food and Animal Sciences, Chungbuk National University, Cheongju, Republic of Korea 28644 \\ 2 Department of Animal Science and Biotechnology, Chungnam National University, Daejeon, 305-764, Republic of Korea \\ ${ }^{3}$ Planning \& Coordination Division, National Institute of Animal Science, Rural Development Administration, \\ Wanju 55365, Republic of Korea \\ ${ }^{4}$ Department of Animal Resources and Science, Dankook University, Cheonan, 330-714, Republic of Korea
}

(Received 20 June 2018; Accepted 26 March 2019; First published online 7 May 2019)

\author{
Copyright resides with the authors in terms of the Creative Commons Attribution 4.0 South African License. \\ See: http://creativecommons.org/licenses/by/4.0/za \\ Condition of use: The user may copy, distribute, transmit and adapt the work, but must recognize the authors and \\ the South African Journal of Animal Science.
}

\begin{abstract}
Participants in the pig production industry focus on feed and feed additives to improve growth performance and meat quality of pigs. Consequently, the Rural Development Administration of the Republic of Korea produced a new paternal line to improve economic traits in pigs. However, there is an absence of information on pig traits with regard to season and sex, and a comparison between the new paternal line and past paternal lines. Therefore, the authors conducted this study to investigate the influence of season of birth, sex and paternal line on growth performance and carcass traits in pigs. A total of 2888 piglets ((Landrace $\times$ Yorkshire) $\times$ Darby Duroc (DD) or Chookjin Duroc (CD)) with an average age of three weeks were tested for 22 weeks during the four season of the year (spring 608 piglets, summer 404 piglets, autumn 576 piglets and winter 1300 piglets). The bodyweights (BW) of individual pig were recorded, and feed consumption was recorded at weeks 2, 12 and 22, to determine growth performance. At reaching market weight, backfat thickness was determined at the last rib area. Meat was graded according to the criteria of the slaughterhouse. There were no significant differences in growth performance and carcass traits between sexes. The CD line crossbred pig had a significant higher BW at 16 weeks, and higher carcass trait values at 22 weeks than the DD line. During weeks 8 to 16 the CD line crossbred pigs showed a tendency of an increased average daily gain (ADG) and gain : feed (G : F) ratio compared with the DD line. Furthermore, pigs born in spring had significant lower ADG, average daily feed intake (ADFI) and carcass trait values than born in the other seasons. In conclusion, the new paternal line (Chookjin Duroc) improved growth performance and carcass traits compare with the DD line.
\end{abstract}

Keywords: sex, growth, terminal sire, meat quality, backfat thickness

* These authors contributed equally to this work

\# Corresponding authors: hbkim@dankook.ac.kr \& jinhcho@cbnu.ac.kr

\section{Introduction}

Traditionally, the pig breeds producing the pork consumed in Republic of Korea were (Landrace $\times$ Yorkshire) $\times$ Duroc crosses. Duroc was used because the paternal line has outstanding meat quality, and the Republic of Korea therefore imported Duroc semen. Yet sometimes there was an imbalance in supply and demand for farmers. Through genetic selection for 10 years, the Rural Development Administration of the Republic of Korea developed a new paternal line (Chookjin Duroc) which is a cross between the Duroc and a Korean native pig, in order to adjust the balance of supply and demand and improve growth performance and meat quality of pigs. From 75 to $116 \mathrm{~kg} \mathrm{BW}$, barrows had higher average daily feed intakes (ADFI) and average daily gains (ADG) than gilts, and higher ADFIs than gilts from 116 to $124 \mathrm{~kg}$ (Latorre et al., 2004). Carcasses produced by the barrows were heavier than those of the gilts, even though other studies reported that carcass weight and yield were not affected by sex (Latorre et al., 2003; 2004). Backfat thickness was 
affected, with intact females having a lower backfat thickness than males (Peinado et al., 2008). However, no basic investigations have been done on the new paternal line, nor comparative studies with the existing paternal line. Additionally, few studies have been conducted to find out how season influences growth performance and carcass traits and how the paternal line influences growth performance and carcass traits in pigs. As social income levels have improved, preference for better meat quality is increasing, and participants in the pig industry have focused on feeds and feed additives to improve the growth performance and meat quality of pigs. Therefore, the present study was designed to evaluate the influence of season of birth, sex and paternal line on growth performance and carcass traits of pigs.

\section{Materials and Methods}

The experimental protocol that was used in this study was approved by the Animal Care and Use Committee of Chungbuk National University, Republic of Korea.

The experiment was conducted with 281 sows (Landrace $\times$ Yorkshire) between September 2016 and June 2018. The sows were inseminated twice at 12-hour intervals with semen from Duroc (Darby Genetics Inc., Anseong, Republic of Korea) or Chookjin Duroc (Rural Development Administration, Suwon, Republic of Korea) boars for the duration of the oestrus. Sows were fed individually twice and had ad libitum access to water. After checking for pregnancy, the sows were moved to environmentally controlled farrowing crates (5.2

Table 1 Ingredient and calculated composition of the diet (as-fed basis)

\begin{tabular}{|c|c|c|c|}
\hline Items & $\begin{array}{c}\text { Phase } 1 \\
\text { (0 to } 8 \text { weeks) }\end{array}$ & $\begin{array}{c}\text { Phase } 2 \\
\text { (8 to } 16 \text { weeks) } \\
\end{array}$ & $\begin{array}{c}\text { Phase } 3 \\
\text { (16 to } 22 \text { weeks) }\end{array}$ \\
\hline \multicolumn{4}{|l|}{ Ingredients, \% } \\
\hline Corn & 43.35 & 42.75 & 43.85 \\
\hline Soybean meal, 48\% & 27.80 & 34.00 & 15.00 \\
\hline Lactose & 8.00 & - & - \\
\hline Oats & - & 12.80 & 32.80 \\
\hline Whey dried & 4.00 & - & - \\
\hline Fish meal (Menhaden) & 8.00 & - & - \\
\hline Lard & 5.00 & 4.75 & 4.50 \\
\hline L-Lysine-HCl & 0.20 & 0.30 & 0.20 \\
\hline DL-Methionine & 0.40 & 0.40 & 0.40 \\
\hline L-Threonine & 1.00 & 1.00 & 1.00 \\
\hline Di-calcium phosphate & 1.25 & 3.00 & 1.25 \\
\hline Limestone & 0.50 & 0.50 & 0.50 \\
\hline Salt & 0.10 & 0.10 & 0.10 \\
\hline Vitamin premix ${ }^{1}$ & 0.20 & 0.20 & 0.20 \\
\hline Mineral premix ${ }^{2}$ & 0.20 & 0.20 & 0.20 \\
\hline \multicolumn{4}{|c|}{ Calculated composition, $\mathbf{g} / \mathbf{k g}^{3}$} \\
\hline $\mathrm{ME}, \mathrm{Kcal} / \mathrm{kg}$ & 3517 & 3361 & 3280 \\
\hline Crude protein & 238.9 & 227.9 & 160.8 \\
\hline Calcium & 8.91 & 6.50 & 5.40 \\
\hline Phosphorus & 5.79 & 4.25 & 3.53 \\
\hline $\mathrm{Ca}: \mathrm{P}$ ratio & 1.54 & 1.53 & 1.53 \\
\hline Lys & 15.29 & 14.23 & 8.54 \\
\hline Met & 0.80 & 7.25 & 6.43 \\
\hline
\end{tabular}

${ }^{1}$ Provided per kilogram of diet: 4,500 $\mathrm{mg}$ vitamin $\mathrm{A}, 93.75 \mathrm{mg}$ vitamin $\mathrm{D}_{3}, 37.5 \mathrm{mg}$ vitamin $\mathrm{E}, 2.55 \mathrm{mg}$ vitamin $\mathrm{K}_{3}, 3 \mathrm{mg}$ thiamine, $7.5 \mathrm{mg}$ riboflavin, $4.5 \mathrm{mg}$ vitamin $\mathrm{B}_{6}, 24 \mu \mathrm{g}$ vitamin $\mathrm{B}_{12}, 51 \mathrm{mg}$ niacin, $1.5 \mathrm{mg}$ folic acid, $0.2 \mathrm{mg}$ biotin, and 13.5 mg pantothenic acid

${ }^{2}$ Provided per kilogram of diet: $37.5 \mathrm{mg} \mathrm{Zn}\left(\right.$ as $\left.\mathrm{ZnSO}_{4}\right), 37.5 \mathrm{mg} \mathrm{Mn}\left(\right.$ as $\left.\mathrm{MnO}_{2}\right), 37.5 \mathrm{mg} \mathrm{Fe}\left(\right.$ as $\left.\mathrm{FeSO}_{4} \cdot 7 \mathrm{H}_{2} \mathrm{O}\right), 3.75 \mathrm{mg}$ $\mathrm{Cu}$ (as $\mathrm{CuSO}_{4} \cdot 5 \mathrm{H}_{2} \mathrm{O}$ ), $0.83 \mathrm{mg} \mathrm{I}$ (as KI), and $0.23 \mathrm{mg} \mathrm{Se}\left(\mathrm{as} \mathrm{Na}_{2} \mathrm{SeO}_{3} \cdot 5 \mathrm{H}_{2} \mathrm{O}\right.$ )

${ }^{3} \mathrm{ME}$ (as metabolizable energy), $\mathrm{Ca}: \mathrm{P}$ (calcium : phosphorus), Lys (as lysine), and Met (as methionine) 
$\mathrm{m}^{2} ; 2.0 \mathrm{~m} \times 2.5 \mathrm{~m}$ ) in a building installed with a winch curtain. Average outside temperatures were: spring $12.1{ }^{\circ} \mathrm{C}$, summer $28.7{ }^{\circ} \mathrm{C}$, autumn $15.1{ }^{\circ} \mathrm{C}$ and winter $1.6{ }^{\circ} \mathrm{C}$. Inside temperatures were: spring $15.1{ }^{\circ} \mathrm{C}$, summer $24.4^{\circ} \mathrm{C}$, autumn $18.1^{\circ} \mathrm{C}$ and winter $11.6^{\circ} \mathrm{C}$. Within $12 \mathrm{~h}$ of birth, the piglets received an injection of $200 \mathrm{mg}$ iron and were provided with a heating zone, using lamps. The piglets received a second iron injection and male piglets were castrated surgically on Day 3 . Individual piglets were identified by ear notching at Day 14.

Over the four seasons 2888 piglets were housed on two farms, 1444 per farm (50\% DD and 50\% CD line). Seasonal allocations were: spring 608 piglets, summer 404 piglets, autumn 576 piglets and winter 1300 piglets. Each growth period consisted of 22 weeks, divided into three phases, 0 - 8, 8 - 16 and 16 - 22 weeks. The ingredients and the nutrient composition of the basal diet are presented in Table 1 . The diets were formulated to meet or exceed the recommendations of NRC (1998). All pigs had free access to feed and water from feeders and water nipples, respectively, and kept in humidity controlled rooms. At weeks 2,12 and 22 weeks, body weights were measured individually, and feed consumption was recorded to determine ADG, ADFI and gain : feed (G : F) ratio.

After reaching market weight of about $115-120 \mathrm{~kg}$, backfat thickness was measured at the last rib area (65 $\mathrm{mm}$ from the centre-line of the back) using real-time ultrasound (Piglog105, Denmark). The pigs were then transported to the slaughterhouse (Farm-story, Republic of Korea) where they were kept for $5.5 \mathrm{~h}$ and then moved to the slaughtering facility. They were stunned between the ears and eyes by electric shock equipment (259 V $270 \mathrm{~V}$ ), where-after blood was drained through both carotid arteries for over two minutes. The bled-out carcasses were put in hot water for scraping and dehairing. Intestinal organs were removed from below the genital slit, and each carcass was split down the midline. Afterward, the head was removed, and carcass grading was done using the criteria presented in Table 2.

Table 2 Grading criteria of the carcasses after slaughter

\begin{tabular}{cccc}
\hline \multirow{2}{*}{ Grade } & \multicolumn{3}{c}{ Scalding carcass } \\
\cline { 2 - 4 } & Carcass weight $\mathbf{( k g )}$ & Backfat thickness $(\mathbf{m m})$ & Dressing percentage (\%) \\
\hline 3 & $83 \sim 93$ & More than 14.0 & More than 56.0 \\
2 & $80 \sim 98$ & 12.0 & 54.0 \\
1 & & Not included in Grade $1+, 1$ & \\
\hline
\end{tabular}

All data were analysed as a completely randomized design with treatments arranged factorially $(2 \times 2$ $\times 4$ ), using the general linear model program of SAS (SAS Institute, 2008). The model included sex, paternal line and season of birth as the main effects. All data are presented as means; and differences are considered statistically significant at $P<0.05$.

\section{Results}

The growth performances of the pigs according to sex, paternal line and season of birth are presented in Table 3. There were no significant differences $(P>0.05)$ in BW, ADG, ADFI and G : F ratio between sexes. Initial BW and BW at 8 weeks were not affected $(P>0.05)$ by paternal line, but the CD line crossbred pig had a higher $(P<0.05)$ BW at 16 and 22 weeks than the DD line. In weeks $0-8$ and $16-22$, paternal line did not affect $(P>0.05)$ growth performance, but during 8 to 16 weeks the CD line crossbred pig showed a tendency of improved ADG and the $G$ : F compared with the DD line $(P=0.051 ; P=0.062)$. The ADG and $G$ : $F$ improved over the total period. Pigs born in autumn had lower $(P<0.05)$ BWs at birth and at 22 weeks than during the other seasons. However, the ADG and ADFI of pigs born in spring were lower $(P<0.05)$ at $0-8,8$ - 16, 16 - 22 and 0 - 22 weeks than those born during the other seasons.

Carcass traits of pigs according to sex, paternal line and the season of birth are presented in Table 4. There were no significant differences $(P<0.05)$ in backfat thickness and pork grade between sexes. The CD line increased $(P<0.05)$ backfat thickness compared with the DD line. Additionally, pigs born of CD had a higher pork grade $(P<0.05)$ than the DD line. In the season of birth, pigs born in spring and autumn had lower $(P<0.05)$ backfat thickness and pork grades than those born in the other seasons. 
Table 3 Influence of sex, paternal line and season of birth on growth performance in pigs ${ }^{1}$

\begin{tabular}{|c|c|c|c|c|c|c|c|c|c|c|c|c|c|c|}
\hline \multirow{2}{*}{ Items $^{2}$} & \multicolumn{2}{|c|}{$\operatorname{Sex}(G)$} & \multirow{2}{*}{ SEM $^{3}$} & \multicolumn{2}{|c|}{ Paternal line (P) } & \multirow{2}{*}{ SEM $^{3}$} & \multicolumn{4}{|c|}{ Season of birth (SB) } & \multirow{2}{*}{ SEM $^{3}$} & \multicolumn{3}{|c|}{ Significance $^{4}$} \\
\hline & CM & $\mathbf{F}$ & & DD & $C D$ & & Spring & Summer & Autumn & Winter & & $\mathbf{G}$ & $\mathbf{P}$ & BS \\
\hline \multicolumn{15}{|l|}{ BW, kg } \\
\hline Initial & 6.13 & 6.14 & 0.04 & 6.14 & 6.15 & 0.04 & 6.39 & 6.25 & 5.77 & 6.26 & 0.08 & NS & NS & * \\
\hline 8 weeks & 33.41 & 33.55 & 0.14 & 33.37 & 34.30 & 0.17 & 34.89 & 33.14 & 32.40 & 35.11 & 0.21 & NS & NS & * \\
\hline 16 weeks & 77.39 & 77.64 & 0.20 & 77.14 & 78.14 & 0.25 & 77.56 & 78.13 & 77.33 & 78.52 & 0.29 & NS & * & * \\
\hline 22 weeks & 113.16 & 113.27 & 0.16 & 112.26 & 114.26 & 0.15 & 112.66 & 114.79 & 110.20 & 115.23 & 0.21 & NS & * & * \\
\hline \multicolumn{15}{|l|}{0 - 8 weeks } \\
\hline $\mathrm{ADG}, \mathrm{kg}$ & 0.49 & 0.49 & 0.05 & 0.49 & 0.49 & 0.04 & 0.51 & 0.48 & 0.48 & 0.51 & 0.02 & NS & NS & * \\
\hline ADFI, kg & 0.82 & 0.83 & 0.12 & 0.82 & 0.82 & 0.08 & 0.75 & 0.72 & 0.74 & 0.75 & 0.28 & NS & NS & NS \\
\hline G: F ratio & 0.60 & 0.59 & 0.09 & 0.60 & 0.60 & 0.02 & 0.68 & 0.67 & 0.65 & 0.68 & 0.03 & NS & NS & NS \\
\hline \multicolumn{15}{|c|}{8 - 16 weeks } \\
\hline ADG, $\mathrm{kg}$ & 0.79 & 0.78 & 0.04 & 0.78 & 0.80 & 0.03 & 0.76 & 0.73 & 0.76 & 0.80 & 0.13 & NS & 0.051 & * \\
\hline ADF, kg I & 2.30 & 2.32 & 0.09 & 2.32 & 2.32 & 0.02 & 2.15 & 2.23 & 2.24 & 2.33 & 0.03 & NS & NS & * \\
\hline G: F ratio & 0.60 & 0.59 & 0.03 & 0.59 & 0.61 & 0.03 & 0.34 & 0.36 & 0.36 & 0.34 & 0.02 & NS & 0.062 & NS \\
\hline \multicolumn{15}{|c|}{16 - 22 weeks } \\
\hline ADG, $\mathrm{kg}$ & 0.85 & 0.85 & 0.02 & 0.84 & 0.87 & 0.02 & 0.87 & 0.81 & 0.88 & 0.90 & 0.22 & NS & NS & * \\
\hline ADFI, kg & 2.53 & 2.55 & 0.21 & 2.54 & 2.54 & 0.04 & 2.22 & 2.58 & 2.49 & 2.49 & 0.08 & NS & NS & * \\
\hline G: F ratio & 0.56 & 0.55 & 0.16 & 0.55 & 0.58 & 0.01 & 0.31 & 0.34 & 0.31 & 0.36 & 0.12 & NS & NS & NS \\
\hline \multicolumn{15}{|c|}{0 - 22 weeks } \\
\hline $\mathrm{ADG}, \mathrm{kg}$ & 0.70 & 0.70 & 0.05 & 0.69 & 0.75 & 0.02 & 0.68 & 0.72 & 0.71 & 0.73 & 0.01 & NS & * & * \\
\hline ADFI, kg & 1.59 & 1.58 & 0.17 & 1.60 & 1.60 & 0.17 & 1.52 & 1.60 & 1.56 & 1.59 & 0.02 & NS & NS & * \\
\hline G: F ratio & 0.44 & 0.44 & 0.08 & 0.43 & 0.48 & 0.02 & 0.42 & 0.44 & 0.44 & 0.45 & 0.02 & NS & * & NS \\
\hline
\end{tabular}

${ }^{1} \mathrm{CM}$ : castrated male; F: female; DD: Darby Duroc, CD: Chookjin Duroc

${ }^{2}$ BW: body weight; ADG: average daily gain; ADFI: average daily feed intake; G : F ratio: gain to feed ratio

${ }^{3}$ SEM: standard error of mean

${ }^{4} \mathrm{NS}$ : no significant difference

${ }^{\star} P<0.05$ 
Table 4 Influence of sex, paternal line and season of birth on carcass traits in pigs ${ }^{1}$

\begin{tabular}{|c|c|c|c|c|c|c|c|c|c|c|c|c|c|c|}
\hline \multirow{2}{*}{ Items $^{2}$} & \multicolumn{2}{|c|}{$\operatorname{Sex}(G)$} & \multirow{2}{*}{ SEM $^{2}$} & \multicolumn{2}{|c|}{ Paternal line (P) } & \multirow{2}{*}{ SEM $^{2}$} & \multicolumn{4}{|c|}{ Season of birth (BS) } & \multirow{2}{*}{ SEM $^{2}$} & \multicolumn{3}{|c|}{ Significance $^{3}$} \\
\hline & CM & $F$ & & DD & CD & & Spring & Summer & $\begin{array}{c}\text { Autum } \\
\mathrm{n}\end{array}$ & Winter & & $\mathbf{G}$ & $\mathbf{P}$ & BS \\
\hline $\begin{array}{l}\text { Backfat } \\
\text { thickness }\end{array}$ & 22.04 & 21.85 & 0.52 & 21.90 & 22.98 & 0.22 & 20.51 & 21.81 & 21.21 & 22.17 & 0.08 & NS & * & * \\
\hline Pork grade & 1.82 & 1.81 & 0.22 & 1.81 & 1.97 & 0.07 & 1.32 & 1.85 & 1.42 & 1.85 & 0.09 & NS & * & * \\
\hline
\end{tabular}

${ }^{1} \mathrm{CM}$ : castrated male; F: female; DD: Darby Duroc; CD, Chookjin Duroc

${ }^{2}$ SEM: standard error of mean

${ }^{3} \mathrm{NS}$ : no significant difference

${ }^{\star} P<0.05$ 


\section{Discussion}

The current trend in the pig production is to improve the reproductive performance such as parity, growth, and meat quality of sows. Sows have been developed steadily to meet these requirements. Additionally, many researchers have studied essential traits such as growth performance, nutrient digestibility and meat quality because pigs are changing genetically. As a new paternal line was developed and pigs changed, it was necessary to investigate the effects of sex, the new paternal line, and the season of birth on these basic traits of pigs.

Many researchers reported that barrows had better growth than gilts owing to their greater feed intake (Langlois \& Minvielle, 1989; Leach et al., 1996; Augspurger et al., 2002). However, Renaudeau et al. (2006) reported that sex did not affect growth performance. In the current results, there was no significant difference $(P<0.05)$ in growth performance between sexes. These results suggest that the current pigs were not affected by sex when they were in the same environmental conditions such as temperature and rearing density. Additionally, the reduction of sex difference on growth rate is considered in the new paternal line because results by Cisneros et al. (1996) showed that sex difference could vary with genotype.

Duroc crossbred pigs showed a tendency to increase initial BW compared with Iberian (IB) when they were at similar ages. Moreover, Duroc crossbred pigs grew about $20 \%$ faster than IB over the growth period (Ventanas et al., 2006). The Duroc had an outstanding growth rate compared with other paternal line. The Chookjin Duroc was developed for 10 years in the Republic of Korea through selecting and using Duroc pigs with high performances. In the present results, CD crossbred pigs had higher $(P<0.05)$ BW at eighth and 22 weeks, and $A D G$ and $G$ : $F$ ratios over the total period than DD crossbred pigs, but there was no significant difference in ADFI among the offspring of the paternal lines. This improvement of the CD line might be due to differences in the genetics programme reported in the results of Ramírez \& Cava (2007) for example.

With regard to the effect of the season on growth, pigs born in autumn had lower initial BW than pigs born in other seasons. Summer heat stress causes many health problems such as anoestrus, low farrowing rates and depressed litter size (Bertoldo et al., 2012). All sows that gave birth in autumn underwent heat stress. Thus, depressed growth in piglets in autumn was due to lower circulating immunoglobulin $\mathrm{G}$ similar to the results of Machado-Neto et al. (1987), and low supplementation of milk from the sow. Furthermore, low initial weight in piglets in autumn lasted until the end of the experiment. Generally, food intake and weight gain of growing and finishing pigs decreased with rising environmental temperatures (Quiniou et al., 2000). In the present results, pigs born in spring had a lower $(P<0.05)$ ADG and ADFI than in other seasons, except for autumn. This is because they underwent heat stress during the growing-finishing phase. Additionally, this reduction was because of decreasing feed intake owing to heat stress.

The present results showed that there was no significant difference in backfat thickness and pork grade between sexes. Previous studies showed that sex did not affect carcass yield and dressing percentages (Fortin, 1980; Leach et al., 1996; Hamilton et al., 2000; Lebret et al., 2001). Moreover, Latorre et al. (2003) did not observe differences in carcass yield between sexes. However, Langlois \& Minvielle (1989) and Ellis et al. (1996) reported that gilts had higher carcass yields than barrows. The discrepancy in results between the current study and other studies is considered to be related to differences in the method used for grading the pork. The standard values (that is, of slaughterhouses in the Republic of Korea) in the current experiment showed significant variation. In the results of the paternal line, pigs from the CD line had higher $(P<0.05)$ backfat thickness and pork grades than those from the DD line. Some researchers reported that traits of fatness generally have a high heritability, with heritability estimates for ultrasonic backfat thickness ranging from 0.35 to 0.72 (Hoque et al., 2007; Solanes et al., 2009). Therefore, the improvement in carcass traits was due to increasing fat in the $C D$ line. Moreover, further research is needed to understand the relationship between sex and paternal line on carcass traits.

Heat stress can reduce carcass traits directly. In the current results, pigs born in spring had lower $(P$ $<0.05$ ) backfat thickness and pork grades than those born during other seasons except for autumn. This is in agreement with the findings of Spencer et al. (2005) and White et al. (2008), who found that carcass fat quality decreased when heat stress occurred.

\section{Conclusion}

This experiment showed that after castrating, growth performance and carcass traits were not affected by sex. Also, improved growth performance and carcass traits were evident in the new paternal line, Chookjin Duroc, but resistance to heat stress did not change.

\section{Acknowledgements}

This work was carried out with the support of Cooperative Research Programme for Agriculture Science \& Technology Development (Project No. PJ01261502)" Rural Development Administration, Republic of Korea. 


\section{Authors' Contributions}

JHC and HBK were in charge of project design. WY and DJY supervised the course of the study. SDL, CHL, WGK, $\mathrm{HJO}$ and JSA were in charge of measurement of body weight and sample collection in pigs. JHL and MHS summarized the results and wrote the manuscript and revised it.

\section{Conflict of Interest Declaration}

The authors declare that they have no conflict of interest.

\section{References}

Augspurger, N.R., Ellis, M., Hamilton, D.N., Wolter, B.F., Beverly, J.L. \& Wilson, E.R., 2002. The effect of sire line on the feeding patterns of grow-finish pigs. Appl. Anim. Behav. Sci. 75, 103-114.

Bertoldo, M.J., Holyoake, P.K., Evans, G. \& Grupen, C.G., 2012. Seasonal variation in the ovarian function of sows. Reprod. Fertl. Dev. 24, 822-834.

Cisneros, F., Ellis, M., McKeith, F.K., McCaw, J. \& Fernando, R.L., 1996. Influence of slaughter weight on growth and carcass characteristics, commercial cutting and curing yields, and meat quality of barrows and gilts from two genotypes. J. Anim. Sci. 74, 925-933.

Ellis, M., Webb, A.J., Avery, P.J. \& Brown, I., 1996. The influence of terminal sire genotype, sex, slaughter weight, feeding regime and slaughter-house on growth performance and carcass and meat quality in pigs and on the organoleptic properties of fresh pork. Anim. Sci. 62, 521-530.

Fortin, A., 1980. The effect of slaughter weight on the carcass characteristics of Yorkshire barrows and gilts. Can. J. Anim. Sci. 60, 265-274.

Gispert, M., Faucitano, L., Oliver, M.A., Guàrdia, M.D., Coll, C., Siggens, K., Harvey, K. \& Diestre, A., 2000. A survey of pre-slaughter conditions, halothane gene frequency, and carcass and meat quality in five Spanish pig commercial abattoirs. Meat Sci. 55, 97-106.

Guàrdia, M.D., Estany, J., Balasch, S., Oliver, M.A., Gispert, M. \& Diestre, A., 2004. Risk assessment of PSE condition due to pre-slaughter conditions and RYR1 gene in pigs. Meat Sci. 67, 471-478.

Guàrdia, M.D., Estany, J., Balasch, S., Oliver, M.A., Gispert, M. \& Diestre, A., 2005. Risk assessment of DFD meat due to pre-slaughter conditions in pigs. Meat Sci. 70, 709-716.

Hamilton, D.N., Ellis, M., Miller, K.D., McKeith, F.K. \& Parrett, D.F., 2000. The effect of the Halothane and Rendement Napole genes on carcass and meat quality characteristics of pigs. J. Anim. Sci. 78, 2862-2867.

Hoque, M.A., Suzuki, K., Kadowaki, H., Shibata, T. \& Oikawa, T., 2007. Genetic parameters for feed efficiency traits and their relationships with growth and carcass traits in Duroc pigs. J. Anim. Breed. Genet. 124, 108-116.

Langlois, A. \& Minvielle, F., 1989. Comparisons of three-way and backcross swine. I. Growth performance and commercial assessment of the carcass. J. Anim. Sci. 67, 2018-2024.

Latorre, M.A., Lázaro, R., Gracia, M.I., Nieto, M. \& Mateos, G.G., 2003. Effect of sex and terminal sire genotype on performance, carcass characteristics, and meat quality of pigs slaughtered at $117 \mathrm{~kg}$ body weight. Meat Sci. 65, 1369-1377.

Latorre, M.A., Lázaro, R., Valencia, D.G., Medel, P. \& Mateos, G.G., 2004. The effects of gender and slaughter weight on the growth performance, carcass traits, and meat quality characteristics of heavy pigs. J. Anim. Sci. 82, 526-533.

Leach, L.M., Ellis, M., Sutton, D.S., McKeith, F.K. \& Wilson, E.R., 1996. The growth performance, carcass characteristics and meat quality of halothane carrier and negative pigs. J. Anim. Sci. 74, 934-943.

Lebret, B., Juin, H., Noblet, J. \& Bonneau, M., 2001. The effects of two methods of increasing age at slaughter on carcass and muscle traits and meat sensory quality in pigs. Anim. Sci. 72, 87-94.

NRC, 1998. Nutrient requirements of swine. 10th edition. National Academic Press, Washington, DC, USA.

Machado-Neto, R., Graves, C.N. \& Curtis, S.E., 1987. Immunoglobulins in piglets from sows heat-stressed prepartum. J. Anim. Sci. 65, 445-455.

Peinado, J., Medel, P., Fuentetaja, A. \& Mateos, G.G., 2008. Influence of sex and castration of females on growth performance and carcass and meat quality of heavy pigs destined for the dry-cured industry. J. Anim. Sci. 86, $1410-1417$

Quiniou, N., Dubois, S. \& Noblet, J., 2000. Voluntary feed intake and feeding behaviour of group-housed growing pigs are affected by ambient temperature and body weight. Livest. Prod. Sci. 63, 245-253.

Ramírez, R. \& Cava, R., 2007. Carcass composition and meat quality of three different Iberian $\times$ Duroc genotype pigs. Meat Sci. 75, 388-396.

Renaudeau, D., Giorgi, M., Silou, F. \& Weisbecker, J.L., 2006. Effect of breed (lean or fat pigs) and sex on performance and feeding behaviour of group housed growing pigs in a tropical climate. Asian-Austral. J. Anim. Sci. 19, 593.

Serrano, M.P., Valencia, D.G., Nieto, M., Lázaro, R. \& Mateos, G.G., 2008. Influence of sex and terminal sire line on performance and carcass and meat quality of Iberian pigs reared under intensive production systems. Meat Sci. 78, 420-428.

Solanes, F.X., Reixach, J., Tor, M., Tibau, J. \& Estany, J., 2009. Genetic correlations and expected response for intramuscular fat content in a Duroc pig line. Livest. Sci. 123, 63-69.

Spencer, J.D., Gaines, A.M., Berg, E.P. \& Allee, G.L., 2005. Diet modifications to improve finishing pig growth performance and pork quality attributes during periods of heat stress. J. Anim. Sci. 83, 243-254.

Statistical Analysis Systems Institute, 2008. SAS user's guide: Statistics, version 9.3. SAS Institute Inc., Cary, NC, USA. 
Ventanas, S., Ventanas, J., Jurado, Á. \& Estévez, M., 2006. Quality traits in muscle biceps femoris and back-fat from purebred Iberian and reciprocal Iberian $\times$ Duroc crossbred pigs. Meat Sci. 73, 651-659.

White, H.M., Richert, B.T., Schinckel, A.P., Burgess, J.R., Donkin, S.S. \& Latour, M.A., 2008. Effects of temperature stress on growth performance and bacon quality in grow-finish pigs housed at two densities. J. Anim. Sci. 86, 1789-1798. 